Int. J. Agril. Res. Innov. Tech. 10(2): 128-136, December 2020 Available online at https://ijarit.webs.com DOI: https://doi.org/10.3329/ijarit.v10i2.51586

https://www.banglajol.info/index.php/IJARIT

\title{
Effect of different amounts of feeds on growth and production of fishes in pond polyculture
}

\author{
S. Sultana ${ }^{{ }^{*}}$, M.S. Rahman ${ }^{1}$, K.A. Jackshay ${ }^{2}$ and K. Hasan² \\ Received 28 September 2020, Revised 12 December 2020, Accepted 24 December 2020, Published online 31 December 2020
}

\begin{abstract}
A B S T R A C T
An experiment was carried out to evaluate the effects of different amounts of supplementary feeds on growth and production of fishes in polyculture where four different species such as rui (Labeo rohita), mrigal (Cirrhinus mrigala), common carp (Cyprinus carpio) and tilapia (Oreochromis niloticus) were cultured in 6 ponds under three treatments, each with two replications. Eighty fish per decimal were stocked along with the stocking ratio of 1:1:1:1 in all the treatments. Supplementary feeds of rice bran and wheat bran (1:1), at the amount of $5 \%$ of body weight were applied in 2 ponds (treatment I) as well as at the amount of $3 \%$ of body weight were used in 2 ponds (treatment II) and 2 ponds (treatment III) were as control where no supplementary feed was used. Urea and T.S.P were applied fortnightly at the rate of $60 \mathrm{~g} \mathrm{decimal}^{-1}$ and $90 \mathrm{~g} \mathrm{decimal}^{-1}$, respectively under all treatments. Physico-chemical and biological factors such as air and water temperature, transparency, rainfall, $\mathrm{pH}$, dissolved oxygen, free $\mathrm{CO}_{2}$, total alkalinity, $\mathrm{PO}_{4}-\mathrm{P}$ and $\mathrm{NO}_{3}-\mathrm{N}$, phytoplankton and zooplankton were studied fortnightly and the limnological conditions were more or less similar in the experimental ponds under three treatments. The calculated gross and net fish productions of fishes under treatment I, treatment II and treatment III were 8.87 and 7.33 ton ha- $\mathrm{yr}^{-1}$, 7.12 and 5.58 ton $\mathrm{ha}^{-1} \mathrm{yr}^{-1}$ and 4.69 and 3.16 ton $\mathrm{ha}^{-1} \mathrm{yr}^{-1}$, respectively. Percent increased of net fish productions of treatment I and treatment II were $231.97 \%$ and $176.59 \%$ higher than that of treatment III (control). The present study reveals that supplementary feeding in fish culture should be done along with fertilization because supplementary feeds are very important to enhance growth of fishes significantly.
\end{abstract}

Keywords: Amounts of feed, Production of fish, Environmental factors, Pond, Polyculture.

${ }^{1}$ Department of Fisheries Management, Bangladesh Agricultural University, Mymensingh, Mymensingh-2202.

${ }^{2}$ Upazila Fisheries Officer, Department of Fisheries, Ministry of Fisheries and Livestock, Govt. of People's Republic of Bangladesh.

*Corresponding author's email: ronybau14@gmail.com (S. Sultana)

Cite this article as: Sultana, S., Rahman, M.S., Jackshay, K.A. and Hasan, K. 2020. Effect of different amounts of feeds on growth and production of fishes in pond polyculture. Int. J. Agril. Res. Innov. Tech. 10(2): 128-136. https://doi.org/10.3329/ijarit.v10i2.51586

\section{Introduction}

Bangladesh is ideally a land for fish production, having one of the highest per capita water ratios in the world. As we know, Bangladesh is a riverine and maritime country. All these water bodies offer tremendous scope and potentiality for increasing fish production by adopting proper management techniques. The role played by fisheries resources of Bangladesh in food, nutrition, economy, employment, earning foreign exchange as well as socio-cultural heritage of the nation is, in a word, enormous.

Bangladesh is one of the world's leading fish producing countries with a total production of 42.77 lakh MT, where aquaculture contributes 56.24 percent to total production (FRSS, 2018).
Bangladesh has ranked $3^{\text {rd }}$ in the world in terms of inland fish production in 2018 (FAO, 2018). Fisheries sector is playing a very significant role in the socioeconomic development, and deserve potential for future development in the agrarian economy of Bangladesh. This sector is contributing significantly in food security through proving safe and quality animal protein; almost 60 percent animal protein comes from fish (FRSS, 2018). It contributes 3.61 percent to our national GDP and around one-fourth (24.41 percent) to the agricultural GDP (DoF, 2018). Over the last three decades, the fish production has increased more than five times (7.54 MT in 1983-84 to 41.34 lakh MT in 2016-17) (FRSS, 2018). 
The demand of fish for human consumption is increasing rapidly day by day with the increasing population. So, it is very important to concentrate on the immediate action to take for enhancing the production of fish to fulfill the demand of the increasing population in terms of food, nutrition, employment as well as foreign exchange earnings. Improved techniques should be applied and management practices should be developed to get higher fish production. Application of supplementary diet along with fertilizer is one of the most important techniques; by applying fertilizer, we can increase fish production. Modern fish culture means improvement of cultural practices through adopting different measures such as proper amount of supplementary diets, proper doses of fertilizer application, maintenance of physico-chemical factors, proper selection of culture species, disease prevention and various control measures. However, the practice has to be cost effective so that it can be applicable among the marginal people of our country which will contribute to improve their livelihood. So use of rice bran and wheat bran as supplementary diet can be proved very cost effective as well as useful for the production and growth of fishes in polyculture system because these are easily available in Bangladesh. Supplementary diet is known to increase the carrying capacity of culture systems and can enhance fish production by many folds. The use of supplementary feed in carp culture has become inevitable for the success of fish culture (Shahzadi et al., 2006).

Table 1. Layout of the experiment.
Although many attempts have been made to understand the effect of supplementary feeds but in earthen pond, polyculture system use of supplementary feed like rice brane and wheat bran along with fertilizer TSP and Urea, a very few studies have been done. Considering the dynamic effects of these supplementary feeds, the experiment on the effects of different amounts of supplementary feeding on production of rui (Labeo rohita), mrigal (Cirrhinus mrigala), Common carp (Cyprinus carpio) and tilapia (Oreochromis niloticus) was undertaken to evaluate the effects of supplementary feeding of rice bran and wheat bran under three different treatments.

\section{Materials and Methods}

In order to investigate the effect of different amounts of feeds on growth and production of fishes in pond polyculture an experiment was carried out in six ponds. All the experimental ponds were arbitrarily numbered as pond no. 1 (P1), pond no. 2 (P2), pond no. $3\left(\mathrm{P}_{3}\right)$, pond no. 4 $\left(\mathrm{P}_{4}\right)$, pond no. $5\left(\mathrm{P}_{5}\right)$ and pond no. 6 (P6) for the convenience of the research.

\section{Experimental layout}

The experimental layout has been given in the table below (Table 1):

\begin{tabular}{|c|c|c|c|c|}
\hline $\begin{array}{l}\text { Treatment } \\
\text { and pond no. }\end{array}$ & $\begin{array}{c}\text { Kind of feed and amount } \\
\text { used }\end{array}$ & $\begin{array}{l}\text { Fish species, ratio and } \\
\text { population density }\end{array}$ & Replication & Fertilization \\
\hline $\begin{array}{l}\text { Treatment-I } \\
\text { (Pond } 3 \& 5 \text { ) }\end{array}$ & $\begin{array}{c}\text { Rice bran and wheat bran } \\
(1: 1) \text { at } 5 \% \text { of body weight } \\
\text { of fishes }\end{array}$ & $\begin{array}{l}\text { Rui: Mrigal: Common } \\
\text { carp: Tilapia =1:1:1:1; } \\
\text { 8o fishes }\end{array}$ & 2 & \multirow{3}{*}{$\begin{array}{c}\text { Urea } 60 \mathrm{~g}, \\
\text { and T.S.P. } \\
90 \mathrm{~g} \\
\text { decimal-1 } \\
\text { fortnightly }\end{array}$} \\
\hline $\begin{array}{l}\text { Treatment-II } \\
\text { (Pond } 1 \text { \& 2) }\end{array}$ & $\begin{array}{c}\text { Rice bran and wheat bran } \\
(1: 1) \text { at } 3 \% \text { of body weight } \\
\text { of fishes }\end{array}$ & - do- & 2 & \\
\hline $\begin{array}{l}\text { Treatment- } \\
\text { III } \\
\text { (Pond } 4 \text { \& 6) }\end{array}$ & No feed & -do- & 2 & \\
\hline
\end{tabular}

Pond preparation and management: All kinds of undesirable species were removed from the ponds by netting. Then all the ponds were dried, renovated and cleaned of aquatic vegetation of the embankment manually. Liming $(\mathrm{CaO})$ was done in all the ponds at the rate of $1 \mathrm{~kg}$ decimal $^{-1}$ before 7 days of fertilization.

Fertilization of pond: Inorganic fertilizers were used in the ponds fortnightly with the application of urea at the rate of $60 \mathrm{~g} \mathrm{decimal}^{-1}$ and triple super phosphate was applied at the rate of $90 \mathrm{~g} \mathrm{decimal}^{-1}$. TSP and urea were dissolved in water for 24 hours in a plastic bucket and then applied with a mug spreading over the pond surface.
Stocking of fish: After 7 days of fertilization, fishes rui (Labeo rohita), mrigal (Cirrhinus mrigala), common carp (Cyprinus carpio), and tilapia (Oreochromis niloticus) were collected from a fish seed farm and stocked at the rate of total 80 fish per decimal at the ratio of rui: mrigal: common carp: tilapia $=1: 1: 1: 1$, respectively with initial average weight $1.79 \mathrm{~kg}$ and initial average length $10.64 \mathrm{~cm}$.

Supplementary feeds: The mixture of rice bran and wheat bran in ratio of 1:1 were applied once daily in the morning between 8.00 and 9:00 a.m. The required amount of feed was mixed with a little amount of water to make it into thick 'dough' rolled into balls. The balls were then thrown into the ponds. Application of rice bran 
and wheat bran mixture in ratio of $1: 1$ as supplementary feeding was done under treatment-I (amount of feed was 5\% of the body weight of fishes) and treatment-II (amount of feed was $3 \%$ of the body weight of fishes). Fish sampling was done at an interval of 15 days in order to calculate the increase in total weight and to adjust the amount of feed.

\section{Study of water quality parameters:}

\section{Methods for study of physical parameters}

Water depth (m): Depth of water of the experimental ponds was measured with the help of a graduated wooden depth meter.

Transparency $(\mathrm{cm})$ : Water transparency of the experimental ponds was measured by a Secchidisk.

Temperature $\left({ }^{\circ} \mathrm{C}\right)$ : Air and water temperature data were collected from 'Weather Yard' office of the Department of Irrigation and Water Management, BAU, Mymensingh.

\section{Methods for study of chemical parameters}

Dissolved oxygen (mg L $\left.\mathrm{L}^{-1}\right)$ : Dissolved oxygen of water was measured by portable digital dissolved oxygen (DO) meter (model: DO5509, Lutron, made in Taiwan).

$\mathrm{pH}$ (Hydrogen-ion concentration): $\mathrm{pH}$ was determined by a portable digital $\mathrm{pH}$ meter (Hanna Instruments, Italy, model-H 196107).

Free carbon dioxide (mg $\left.\mathrm{L}^{-1}\right)$ : For determining free carbon dioxide of water, samples were collected in $250 \mathrm{ml}$ black plastic bottles and titrated with $0.022 \mathrm{~N}$ sodium hydroxide solution using phenolphthalein as indicator.

Total alkalinity (mg L $\left.\mathrm{L}^{-1}\right)$ : To determine total alkalinity, samples were collected in $250 \mathrm{ml}$ black plastic bottles and total alkalinity of water samples was determined by titrimentric method using methyl orange indicator.

Phosphate-phosphours (PO4-P) (mg L $\left.\mathrm{L}^{-1}\right)$ : Phosphate-phosphorus (PO4-P) of water samples of the ponds was determined by a digital Phosphate Meter (model HI 93717, Hanna Instruments).

Nitrate-nitrogen $\left(\mathrm{NO}_{3}-\mathrm{N}\right) \quad\left(\mathrm{mg}^{-1}\right)$ : Nitrate nitrogen (NO3-N) was determined by a digital Nitrate Meter (model HI 93728, Hanna Instruments.

\section{Methods for study of biological parameters}

Collection and preservation of plankton samples: Water samples in a $500 \mathrm{ml}$ bottle were randomly collected for quantitative and qualitative study of phytoplankton and zooplankton of water from different locations of each of the ponds and passed through a plankton net (mesh-size $55 \mu$ ) and finally concentrated to $100 \mathrm{ml}$. Then concentrated samples were preserved in small plastic bottles in 5\% formalin for study under a compound microscope.

Counting of plankton: Counting of both phytoplankton and zooplankton were done with the help of Sedgwick-Rafter Counting Cell (S-R cell).

Calculation of plankton: The plankton population was determined by Sedgwick Rafter counting Cell (S-R Cell) using the following formula (Rahman, 1992).

$$
\mathrm{N}=\frac{\mathrm{A} \times 1000 \times \mathrm{C}}{\mathrm{V} \times \mathrm{F} \times \mathrm{L}}
$$

Where, $\mathrm{N}=\mathrm{No}$. of plankton cells per liter of original water, $\mathrm{A}=$ Total no. of plankton counted, $\mathrm{C}=$ Volume of final concentrate of the sample in $\mathrm{ml}, \mathrm{V}=$ Volume of a field $=1 \mathrm{~mm}^{3}, \mathrm{~F}=$ No. of the fields counted, $\mathrm{L}=$ Volume of original water in liter.

The number of phytoplankton and zooplankton were expressed as cells $\mathrm{L}^{-1}$.

\section{Estimation of growth and production of fishes}

Finally, the fishes were harvested from all the ponds with the help of a cast net and then rotenone powder was used for complete harvesting and the final length and weight were recorded. Survival rate (\%), net and gross fish production (ton ha $\mathrm{yr}^{-1}$ ) were calculated according to the following formulas:

i) The survival rate was estimated by the following formula:

Survival rate $(\%)=\frac{\text { No.of harvested fish }}{\text { Initial no. of fish }} \times 100$

ii) Gross fish production (ton $\mathrm{ha}^{-1} \mathrm{yr}^{-1}$ )

$=\frac{\text { Gross weight }(\mathrm{kg}) \text { of fish per decimal per month } \times 250 \times 12}{1000}$

iii) Net fish production (ton ha-1 $\mathrm{yr}^{-1}$.)

$=\frac{\text { Net weight }(\mathrm{kg}) \text { of fish per decimal per month } \times 250 \times 12}{1000}$

\section{Results}

\section{Water quality parameters}

During the experimental period, a number of physico-chemical and biological parameters of pond water like average water depth, transparency, air temperature, water temperature, rainfall, dissolved oxygen, free $\mathrm{CO}_{2}$, $\mathrm{pH}$, total alkalinity, $\mathrm{PO}_{4}-\mathrm{P}, \mathrm{NO}_{3}-\mathrm{N}$, plankton were determined. Fortnightly variations and descriptions of all the water quality parameters of the ponds in all treatments have given below: 
Table 2. Study of physical parameters (Mean \pm S.D, $n=3$ ) during the experiment.

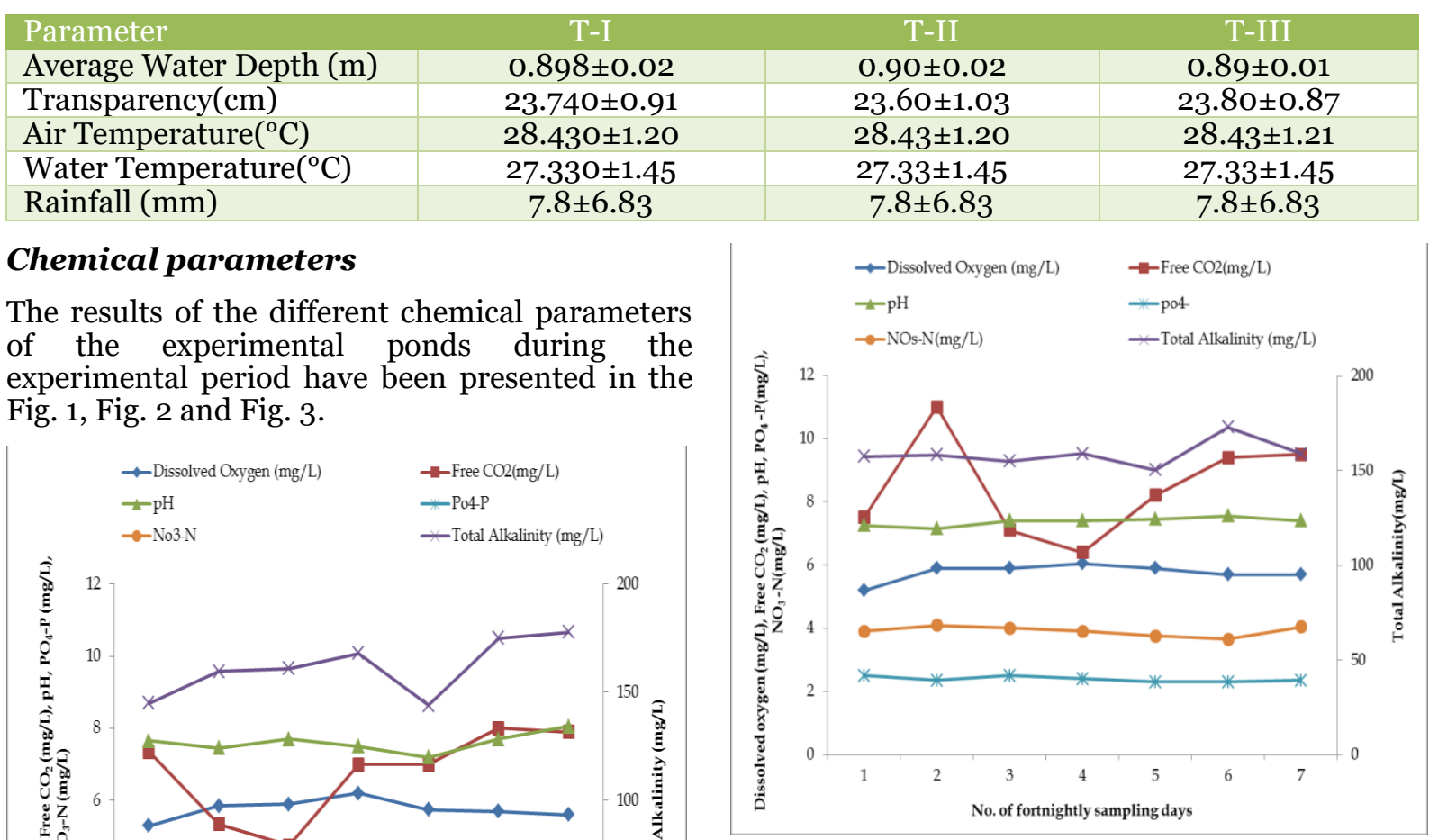

Fig. 3. Fortnightly fluctuation of chemical parameters of the ponds under treatment-III.

\section{Biological parameters}

The results of the conducted experiment, the biological parameters such as phytoplankton and zooplankton cell density (cells $\mathrm{L}^{-1}$ ), genetic status and fluctuation of cell densities of phytoplankton and zooplankton have been presented in Table 3 and 4.

Fig. 1. Fortnightly fluctuation of chemical parameters under treatment-I.

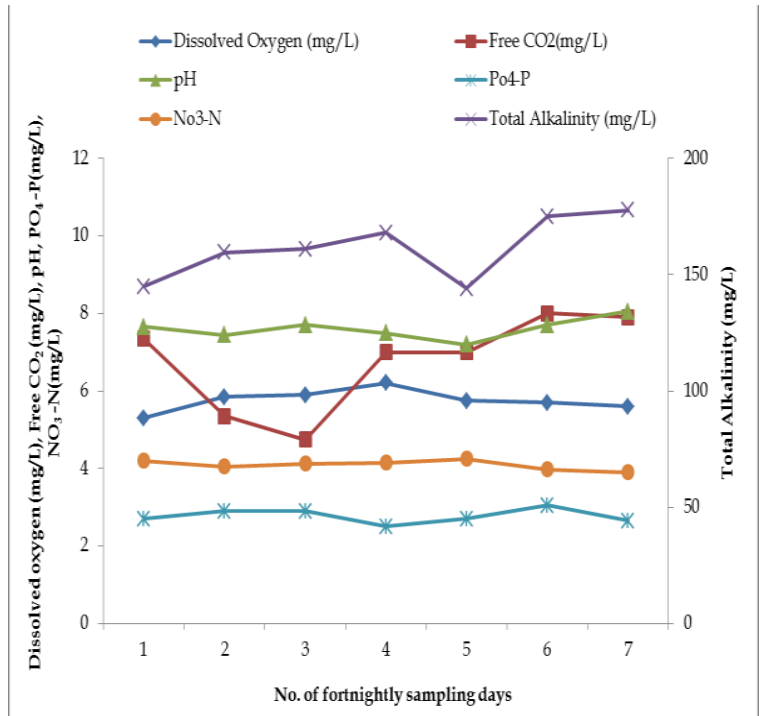

Phytoplankton (cells $\mathrm{L}^{-1}$ ): During the study period, 26 genera of phytoplankton belonging to four groups of Chlorophyceae, Bacillariophyceae, Euglenophyceae and Cyanophyceae were found in all the six ponds. The average density of phytoplankton of the ponds under treatment-I was $76.10 \pm 2.72\left({\left.\mathrm{x} 10^{3}\right)}^{3}\right.$ cells $\mathrm{L}^{-1}$ and that of the ponds under treatment-II was 78.02 \pm 3.63 (x103) cells $\mathrm{L}^{-1}$ and that of the ponds under treatment-III was $67.01 \pm 2.26\left({\left.\mathrm{x} 10^{3}\right)}^{3}\right.$ cells $\mathrm{L}^{-1}$ (Table 4).

Zooplankton (cells $\mathrm{L}^{-1}$ ): During the experimental period, different zooplankton belonging to 3 groups of Rotifera (6 genera), Copepoda (4 genera) and Cladocera (2 genera) were found in all the experimental ponds. The average density of zooplankton of the ponds under treatment-I was $8.03 \pm 0.43\left({\left.\mathrm{x} 10^{3}\right)}^{3}\right.$ cells $\mathrm{L}^{-1}$ and that of the ponds under treatment-II was $7.92 \pm 0.46\left({\left.\mathrm{x} 10^{3}\right)}^{3}\right.$ cells $\mathrm{L}^{-1}$ and that of the ponds under treatment-III

Fig. 2. Fortnightly fluctuation of chemical parameters of the ponds under treatment-II. 
Table 3. Generic status of phytoplankton and Zooplankton found in the experimental ponds under treatments I, II and III.

\begin{tabular}{|c|c|c|c|c|c|c|c|}
\hline \multicolumn{8}{|c|}{ Phytoplankton } \\
\hline \multicolumn{2}{|c|}{ Bacillariophyceae } & \multicolumn{2}{|c|}{ Chlorophyceae } & \multicolumn{2}{|r|}{ Cyanophyceae } & \multicolumn{2}{|c|}{ Euglenophyceae } \\
\hline $\begin{array}{l}1 . \\
2 . \\
3 . \\
4 . \\
5 . \\
6 . \\
7 . \\
8 . \\
9 .\end{array}$ & $\begin{array}{l}\text { Asterionella } \\
\text { Actinella } \\
\text { Coscinodiscus } \\
\text { Cyclotella } \\
\text { Diatom } \\
\text { Fragilaria } \\
\text { Navicula } \\
\text { Nitzchia } \\
\text { Tabellaria }\end{array}$ & $\begin{array}{l}1 . \\
2 . \\
3 . \\
4 . \\
5 . \\
6 . \\
7 . \\
8 . \\
9 .\end{array}$ & $\begin{array}{l}\text { Closterium } \\
\text { Chlorella } \\
\text { Pediastrum } \\
\text { Scenedesmus } \\
\text { Sphaerocystis } \\
\text { Spirogyra } \\
\text { Tetraedon } \\
\text { Ulothrix } \\
\text { Volvox }\end{array}$ & $\begin{array}{l}1 . \\
2 . \\
3 . \\
4 . \\
5 . \\
6 .\end{array}$ & $\begin{array}{l}\text { Anabaena } \\
\text { Aphanocapsa } \\
\text { Gomphosphaeria } \\
\text { Microcystis } \\
\text { Oscillatoria } \\
\text { Pleurosigma }\end{array}$ & $\begin{array}{l}1 . \\
2 .\end{array}$ & $\begin{array}{l}\text { Euglena } \\
\text { Phacus }\end{array}$ \\
\hline \multicolumn{8}{|c|}{ Zooplankton } \\
\hline \multicolumn{8}{|c|}{ Crustacean } \\
\hline \multicolumn{4}{|c|}{ Cladocera } & \multicolumn{2}{|c|}{ Copepoda } & \multicolumn{2}{|c|}{ Rotifera } \\
\hline & $\begin{array}{l}\text { Daphnia } \\
\text { Diaphanosomo } \\
\text { Moina } \\
\text { Nauplius } \\
\text { cean larva) }\end{array}$ & & & & $\begin{array}{l}\text { Cyclops } \\
\text { Diaptomus }\end{array}$ & $\begin{array}{l}1 . \\
2 . \\
3 . \\
4 . \\
5 . \\
6 .\end{array}$ & $\begin{array}{l}\text { Asplanchna } \\
\text { Brachionus } \\
\text { Filinia } \\
\text { Keratella } \\
\text { Polyarthra } \\
\text { Trichocera }\end{array}$ \\
\hline
\end{tabular}

Table 4. Cell densities of phytoplankton and zooplankton of the experimental ponds during the experimental period.

\begin{tabular}{|c|c|c|c|}
\hline Parameters & \multicolumn{3}{|c|}{ Treatment } \\
\hline $\begin{array}{c}\text { Phytoplankton } \\
\left(\times 10^{3}, \text { cells L }-1\right)\end{array}$ & T-I & T-II & T-III \\
\hline $\left.\begin{array}{c}\text { Zooplankton } \\
\left(\times 10^{3}, \text { cells L L }\right.\end{array}\right)$ & $8.03 \pm 0.43$ & $78.02 \pm 3.63$ & $67.01 \pm 2.26$ \\
\hline
\end{tabular}

\section{Survival rate, growth and production of fish}

Survival rate: The survival rate (\%) of fishes were different in the treatments. The mean survival rate of rui, mrigal, common carp and tilapia in treatment-I was $93.75 \%$ and in treatment-II was $91.88 \%$ and in treatment-III was $86.88 \%$.

Production of fish: The gross and net productions of fish of the ponds under treatment I, II and treatment III have been presented in the Table 5 and Fig. 4. The calculated average gross and net productions of all fishes of the ponds under
treatment-I were 8.87 and 7.33 ton $\mathrm{ha}^{-1} \mathrm{yr}^{-1}$; and those of the ponds under treatment-II were 7.12 and 5.58 ton $\mathrm{ha}^{-1} \mathrm{yr}^{-1}$; and those of the ponds under treatment-III were 4.69 and 3.16 ton ha-1 $\mathrm{yr}^{-1}$, respectively (Table 5). The percent increase of net yield $(\mathrm{kg} /$ decimal $/ 3.5$ months) of all fishes of treatments I and II over treatment III were $232.61 \%$ and $176.90 \%$, respectively (Table 5). The calculated percent increase of net yield (ton ha-1 $\mathrm{yr}^{-1}$ ) of all fishes of treatments I and II over treatment III were $231.97 \%$ and $176.59 \%$, respectively (Table 5). 
Table 5. Survival rate, growth and production (gross and net) of fishes of the ponds under treatment I, II and III.

\begin{tabular}{|c|c|c|c|c|c|c|c|c|}
\hline \multirow[t]{2}{*}{ Treatment } & \multirow[t]{2}{*}{$\begin{array}{l}\text { Survival } \\
\text { rate }\end{array}$} & \multirow{2}{*}{$\begin{array}{c}\text { Final total } \\
\text { wt. of fish } \\
\text { (kg/decimal/ } \\
3.5 \text { months) }\end{array}$} & \multirow{2}{*}{$\begin{array}{l}\text { Initial } \\
\text { total wt. } \\
\text { of fish } \\
\text { (kg/ } \\
\text { decimal) }\end{array}$} & \multicolumn{2}{|c|}{$\begin{array}{l}\text { Production } \\
\text { (kg/decimal } \\
\text { /yr) }\end{array}$} & \multicolumn{2}{|c|}{$\begin{array}{l}\text { Production } \\
\left(\text { ton } \mathrm{ha}^{-1} \mathrm{yr}^{-1}\right)\end{array}$} & \multirow{2}{*}{$\begin{array}{c}{ }^{*} \text { Percent } \\
\text { increase } \\
\text { of net } \\
\text { yield of } \\
\text { T-I and } \\
\text { T-II over } \\
\text { T-III }\end{array}$} \\
\hline & & & & Gross & Net & Gross & Net & \\
\hline $\begin{array}{l}\text { T-I } \\
\text { (Rice bran: } \\
\text { Wheat bran=1:1, } \\
5 \% \text { of body } \\
\text { weight+ } \\
\text { Fertilization) }\end{array}$ & 93.75 & 10.34 & 1.79 & 35.47 & 29.33 & 8.87 & $7 \cdot 33$ & $231.97 \%$ \\
\hline $\begin{array}{l}\text { T-II } \\
\text { (Rice bran: } \\
\text { Wheat bran=1:1, } \\
3 \% \text { of body } \\
\text { weight+ } \\
\text { Fertilization) }\end{array}$ & 91.88 & 8.29 & 1.78 & 28.44 & 22.30 & 7.12 & $5 \cdot 58$ & $176.59 \%$ \\
\hline $\begin{array}{l}\text { T-III } \\
\text { (Control+ } \\
\text { Fertilization }\end{array}$ & 86.88 & $5 \cdot 47$ & 1.80 & 18.74 & 12.60 & 4.69 & 3.16 & $100 \%$ \\
\hline
\end{tabular}

*Net production of Treatment III (T-III) was taken for $100 \%$.

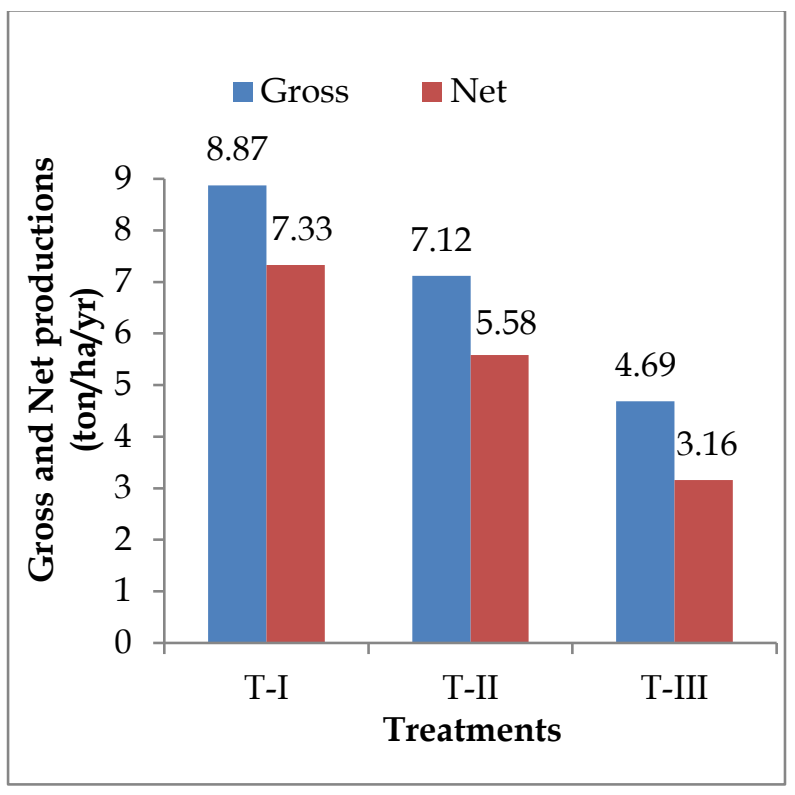

Fig. 4. Gross and Net productions (ton $\mathrm{ha}^{-1} \mathrm{yr}^{-1}$ ) of fish under treatments I, II and III.

\section{Discussion}

Quality of the aquatic environment generally depends on various kinds of factors such as physical factors, chemical factors, biological factors etc. Water qualities of a water body are very important to achieve the maximum production in fish culture. Suitable water quality is prerequisite to maintain a healthy aquatic environment and play a significant role on growth and production of fish and other aquatic organisms, because good growth and production of fishes are the outcomes of aquaculture. The primary productivity of water body is dependent on physical and chemical factors of water in relation to the environmental factors (Rahman, 1992).

\section{Physical parameters}

Water quality, especially chemical qualities almost completely depend on physical parameters. So, physical parameters are very important for fish production. There are various kinds of physical factors such as water depth, transparency, air temperature, water temperature, rainfall etc. All of these physical parameters directly influence on the survival and growth of fishes. Sometimes these factors are uncontrollable but can be managed upon a certain limit by following the proper management practices. Depth of a water body has great significance to the production of aquatic organisms. During the experimental period, fortnightly fluctuations of water depth ranged from 0.85 to $0.94 \mathrm{~m}$. Jhingran (1975) stated that a depth of about $2 \mathrm{~m}$ of a pond is suitable from the viewpoint of biological productivity. Rahman (1992) stated that pond should not be shallower than $\mathrm{lm}$ and deeper than $5 \mathrm{~m}$ and optimum depth should be $2 \mathrm{~m}$.

Reid and Wood (1976) reported that transparency of water usually affected by several factors such as siltation, microscopic organisms, suspended organic matter, latitude, season and the angle, and intensity of sunlight. Transparency showed a variation during the study period due to 
application of fertilizers and rainfall. Rahman (1992) reported that Secchi disc visibility of 40 $\mathrm{cm}$ or less in ponds, if water turbidity is due to plankton, indicates productivity. The range of the transparency recorded during the study was more or less within the productive range in all of the treatments. Reid (1964) reported that the transparency of water was affected by several factors, such as silting, microscopic organisms, suspended organic matter, latitude, season, the angle and intensity of light penetration.

Growth, production and other biological activities of fish are directly influenced by air temperature, which is the very important physical parameter. Throughout the experimental period, the air temperature was found to vary from $24.8^{\circ} \mathrm{C}$ to $33.1^{\circ} \mathrm{C}$. The air temperature was high in the month of July and low in August due to sunshine period, cloudy days, and other seasonal variations. Water temperature is the most important physical factor. For $1^{\circ} \mathrm{C}$ rise of temperature metabolic rate of fish increases $10 \%$. As we know that fish is a poikilothermic animal, so, it influences the growth, production and other biological activities of fish. During the experimental period, the water temperature fluctuated between $25.5^{\circ} \mathrm{C}$ to $29.5^{\circ} \mathrm{C}$ among treatments I, II and III. Murty et al. (1978) recorded temperature range of 24.50 to $32.50^{\circ} \mathrm{C}$ suitable for fish culture, which is very similar to the present study. Jhingran (1991) quoted that the suitable temperature range for the growth of Indian major carps is from $18.8^{\circ} \mathrm{C}$ to $37.8^{\circ} \mathrm{C}$.

\section{Chemical parameters}

Survival rate and growth of fish depend on chemical parameters of the aquatic environment. During the experimental period, all of the chemical parameters were found within the suitable range for fish culture.

Dissolved oxygen (DO) is the most important chemical factor for all aquatic organisms except anaerobic bacteria. Regular supply of dissolved oxygen is required by all the aquatic organisms. Suitability of water for fish and other organisms can be measured from DO value. The sources of dissolved oxygen in pond are primarily through the photosynthesis of phytoplankton and other aquatic plants and secondarily by diffusion from the atmosphere. Various bacterial and other diseases infect fishes if they suffer from insufficient dissolved oxygen for long time. Oxygen depletion occurs in pond water through respiration of fish, benthic organisms, phytoplankton, zooplankton and decomposition of dead organic materials and release to the atmosphere when the water is supersaturated with oxygen. Requirements of dissolved oxygen by fish vary with temperature, physiological state, age, time of the day, species, season, food composition etc. (Boyd, 1982). Temperature and dissolved oxygen show an inverse relationship. According to Rahman (1992), DO content of productive pond should be $5 \mathrm{ppm}$ or more.

During the study period, the dissolved oxygen content of water of the experimental ponds varied from 5.0 to $6.3 \mathrm{mg} \mathrm{L}^{-1}$. In many cases carbondioxide may be considered as a troublesome substance but it is the basis of all life on earth. The basic food production by plants through photosynthesis is not possible without free carbon-dioxide. Bound and half-bound carbondioxide has profound influence on the water quality (Rahman, 1992). According to Lagler (1972), free carbon-dioxide more than $20 \mathrm{mg} \mathrm{L}^{-1}$ may be harmful to fishes. During the experimental period, free carbon dioxide concentration of the ponds under treatment-I, treatment-II and treatment-III varied from varied from $2.3 \mathrm{mg} \mathrm{L}^{-1}$ to $10.0 \mathrm{mg} \mathrm{L}^{-1}, 4.0 \mathrm{mg} \mathrm{L}^{-1}$ to $8.4 \mathrm{mg} \mathrm{L}^{-1}$ and $4.8 \mathrm{mg} \mathrm{L}^{-1}$ to $12.0 \mathrm{mg} \mathrm{L}^{-1}$, respectively.

$\mathrm{pH}$ is treated as the productivity index of water body that's why it is an important chemical factor in fish culture. According to Swingle (1967), pH value of 6.5 to 9.0 is suitable for pond fish culture and $\mathrm{pH}$ more than 9.5 is unsuitable for fish culture. $\mathrm{pH}$ less than 6.5 reduces fish growth, physiological activities and tolerance to toxic substances. Parasites and disease easily attack fish when pH is less than 6.5 (Rahman, 1992). The $\mathrm{pH}$ value of the experimental ponds under treatment-I, treatment-II and treatment-III varied from 6.8 to 8.2 .

The term total alkalinity refers to the total concentration of carbonate, bicarbonate and hydroxide in water expressed in milligrams per liter of equivalent calcium carbonate. Alkalinity does not directly help aquatic biotic production. In alkaline waters, essential nutrients are found in higher quantities and this is the most important reason for higher biological productivity in alkaline waters than in acidic waters. During the study period total alkalinity of the ponds under treatment-I, II \& III ranged from 134 to $182 \mathrm{mg} \mathrm{L}^{-1}$. Rahman (1992) reported that total alkalinity of productive ponds should be $20 \mathrm{ppm}$ or more and total alkalinity usually may range from zero to several hundred ppm. According to Boyd (1982), total alkalinity of productive pond should be $20 \mathrm{ppm}$ or more and fish production increases with the increase of total alkalinity.

Phosphate-phosphorous $\left(\mathrm{PO}_{4}-\mathrm{P}\right)$ is often the most important nutrient related to productivity in aquatic ecosystems (Boyd, 1982). The nutrient phosphorous is a limiting factor for plant growth. It is available in very small quantity all over the world. So, phosphate is very important fertilizer for fish pond. According to Alikunhi (1957), phosphate-phosphorous ranged from 0.20 to 
$0.04 \mathrm{mg} \mathrm{L}^{-1}$ are within good productive range. In the present experiment, phosphate-phosphorous ranges of the ponds were slightly higher than those mentioned in the above statements may be due to regular fertilization.

Nitrate-nitrogen is extremely important as a nutrient in supplying nitrogen for protein synthesis. The range of nitrate-nitrogen values recorded by Das et al. (2005) ranged from 1.60 to $3.22 \mathrm{mg} \mathrm{L}^{-1}$ was more or less close to the values obtained in the present study. According to Bhuiyan (1970), nitrate-nitrogen ranged from 0.06 to $1.00 \mathrm{ppm}$ is of productive rage.

\section{Biological parameters}

Phytoplankton: Fishes mainly take phytoplankton as their main food source that's why the density of phytoplankton population indicates the productive status of a water body. Its abundance in nature is regulated by multiple environmental factors such as temperature, light, dissolved oxygen, $\mathrm{pH}$ and nutrient concentration etc. In the present study, the mean values of the phytoplankton densities were $76.10 \pm 2.72\left(\mathrm{x} 10^{3}\right)$ cells $\mathrm{L}^{-1}, 78.02 \pm 3.63\left(\mathrm{x} 10^{3}\right)$ cells $\mathrm{L}^{-1}$ and $67.01 \pm$

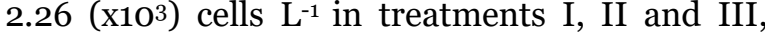
respectively.

Zooplankton: The basic sources of food items for fish are zooplankton. During the study period, the mean values of zooplankton densities were $8.03 \pm 0.43\left({\left.\mathrm{x} 1 \mathrm{O}^{3}\right)}^{2}\right.$ cells $\mathrm{L}^{-1}, 7.92 \pm 0.46\left({\left.\mathrm{x} 1 \mathrm{O}^{3}\right)}^{-1}\right.$ cells $\mathrm{L}^{-1}$ and $7.09 \pm 0.38\left({\left.\mathrm{x} 10^{3}\right)}^{3}\right.$ cells $\mathrm{L}^{-1}$ in treatments I, II and III, respectively.

\section{Survival rate, growth and production of fish}

Survival rate (\%): In the present experiment, the survival rates were different in different experimental ponds. The mean survival rates in treatments I, II and III were $93.75 \%, 91.88 \%$ and $86.88 \%$, respectively. The survival rate was high because before fingerlings release, the experimental ponds were prepared effectively with appropriate doses of lime, urea and TSP.

Growth and Production of fish: Fish fed with supplementary feed grew faster than with only fertilization. In polyculture system, the frequent application of organic, inorganic fertilizers, supplementary feed and culture species ratio make the maintenance of production and the maximum utilization of fish food organisms of pond ecosystems. In the present experiment, calculated gross and net productions of fish of the ponds under treatment 1 (amount of feed was 5\% of the body weight of fishes and use of TSP-90 g and urea-60 $\mathrm{g} \mathrm{decimal}^{-1}$ fortnightly) were 8.87 ton $\mathrm{ha}^{-1} \mathrm{yr}^{-1}$ and 7.33 ton $\mathrm{ha}^{-1} \mathrm{yr}^{-1}$, respectively. In the ponds under treatment II (amount of feed was $3 \%$ of the body weight of fishes and use of
TSP-90g and urea-60 $\mathrm{g}^{\text {decimal }}{ }^{-1}$ fortnightly) were 7.12 ton $\mathrm{ha}^{-1} \mathrm{yr}^{-1}$ and 5.58 ton $\mathrm{ha}^{-1} \mathrm{yr}^{-1}$, respectively. Moreover, those of the ponds under treatment III (control, no supplementary feed was used, only fertilization was done) were 4.69 ton $\mathrm{ha}^{-1} \mathrm{yr}^{-1}$ and 3.16 ton $\mathrm{ha}^{-1} \mathrm{yr}^{-1}$, respectively. The present experiment shows that the net production of fishes of treatments I and II were $232.61 \%$ and $176.90 \%$ higher than that under treatment III.

Hosen et al. (2014) found higher gross and net yields of fish fertilization and artificial feeding application than those in case of only fertilization. Application of artificial feed significantly increased the growth and production of fish more than two times which indicates that artificial feeding in polyculture is very useful for increasing fish production which are more or less similar to those of the present experiment. Abbas et al. (2014) found in an experiment on effect of fertilization and supplementary feeding in polyculture of carps, that fertilization along with supplementary feed is essential for maximum fish yield, which has similarity with those of the present experiment. Zahid et al. (2013) found that GIFT strain tilapia's growth and production was much better in pond with fertilization and artificial feed than those in pond with only fertilization. Hossain et al. (2013) found highest production of fishes by applying supplementary feed (rice bran and mustard oil cake) than those in pond where only cow dung was used. Babu et al. (2013) found significantly higher growth and production in pond treated with manure and artificial feed than those in pond treated with manure and control pond (no manure and no artificial feed) in an experiment of monoculture of $C$. catla in 3 ponds in India which has similarity with the present experiment. Abdel and Sweilum (2004) concluded in an experiment of tilapia culture using artificial diets, organic fertilizers and found best growth and profit in the ponds with low level of organic fertilizer along with artificial diet.

In the present experiment, all of the physicochemical parameters of the ponds under treatments I, II and III were more or less similar but higher production of fish recorded under treatment I than those of treatments II and III because of the use of feed as rice bran and wheat bran mixture in ratio of 1:1 at an amount of $5 \%$ of fish body weight and use of fertilizer and supplementary feed at an amount of $3 \%$ of fish body weight and use of fertilizers under treatments I and II affect the growth and production of fish significantly than those in treatment III which was control, in which no supplementary feed was used and only fertilization was done fortnightly. 


\section{Conclusion}

The research was conducted to investigate the effects of different amounts of supplementary feeds on the growth and production of fishes (rui, mrigal, common carp and tilapia) in polyculture system. According to the experiment there is no doubt that, the findings have practical importance in maximizing the growth and production of different fishes in polyculture in ponds. All the ponds under three treatments were fertilized. As regards the productions of fishes, the present findings show encouraging results, which can support fish farming and can improve the socio-economic condition of the fish farmers significantly. Further research works should be done on supplementary feeding of different percentage of body weight. However, the present study reveals that supplementary feeding in fish culture should be done along with fertilization because supplementary feeds are very important to enhance growth of fishes significantly.

\section{References}

Abbas, S., Ashraf, M. and Ahmed, I. 2014. Effect of fertilization and supplementary feeding on growth performance of Labeo rohita, Catla catla and Cyprinus carpio. J. Animal Plant Sci. 24(1): 142-148.

Abdel, T.A.A. and Sweilum, M.A. 2004. Improvement of fish production and water quality in tilapia cultured ponds by using different types of artificial diets and organic fertilizers. Vet. Med. J. Giza. 52: 19-28.

Alikunhi, K.H. 1957. Fish Culture in India. Farm Bulletin No. 20, Indian Council of Agricultural Research, New Delhi, India. p. 144.

Babu, S., Shailender, M. and Krishna, P.V. 2013. Effect of fertilization and artificial feed on the growth, condition factor and proximate composition of Indian major carp, Catla catla (Hamilton). Int. J. Res. Fish. Aqua. 3: 57-62.

Bhuiyan, B.R. 1970. Physico-chemical qualities of water of some ancient tanks in Sibsagar, Assam. Environ. Health. 12: 129-369.

Boyd, C.E. 1982. Water Quality Management for Pond Fish Culture. Elsevier Science Publisher BV, 1000 AH Amsterdam, The Netherlands. p. 318.

Das, P.C., Ayyappan, S. and Jena, J. 2005. Comparative changes in water quality and role of pond soil after application of different levels of organic and inorganic inputs. Aqua. Res. 36 (8): 785-798. https://doi.org/10.1111/j.1365-2109.2005.01288.x

DoF. 2018. Matshaw Pakkhaw Sankalon. Department of Fisheries and Livestock. Government of the People's Republic of Bangladesh, Matsya Bhaban, Ramna, Dhaka. pp. 150-151.
FAO. 2018. The State of World Fisheries and Aquaculture, 2018. Food and Agriculture Organization of the United Nations, Rome. p. 16.

FRSS. 2018. Yearbook of Fisheries Statistics of Bangladesh 2017-18. Fisheries Resources Survey System (FRSS), Department of Fisheries Bangladesh, Ministry of Fisheries and Livestock, Government of the People's Republic of Bangladesh. Vol. 35. p. 129.

Hosen, M.A., Shahjahan, M., Rahman, M.S. and Alam, M.J. 2014. Effects of artificial feeds on growth and production of fishes in polyculture, Int. J. Agril. Res. Innov. Tech. 4(2): 11-15.

https://doi.org/10.3329/ijarit.v4i2.22637

Hossain, M.I., Ahmed, S., Reza, M.S., Hossain, M.Y., Islam, M.N., Ara, J. and Islam, R. 2013. Effects of organic fertilizer and supplementary feeds on growth performance of silver carp (Hypophthalmichthys molitrix) and bata (Cirrhinus reha) fry in nursery ponds. Int. J. Res. Appl. Nat. Soc. Sci. 1: 117-124.

Jhingran, V.G. 1975. Aquaplosion Lecture, Summer International, Intensive Freshwater Fish Culture, Cuttack, Organised by Central Inland Fisheries Research Institute, Barrackpore (ICAR), India. p. 12.

Jhingran, V.G. 1991. Fish and Fisheries of India. $3^{\text {rd }}$ edition. Hindustan Publishing Corporation, Delhi, India. p. 727.

Lagler, K.F. 1972. Freshwater Fishery Biology. $2^{\text {nd }}$ edition, WMC, Brown Company Publishers, Dubuque, IOWA. p. 421.

Murty, D.S., Salia, G.N., Selveraj, C., Reddy, P.V.G.K. and Dey, R.K. 1978. Studies on increased fish production in composite fish culture through nitrogenous fertilization, with, and without supplementary feeding. Indian J. Inland Fish. Soc. 10: 39-45.

Rahman, M.S. 1992. Water Quality Management in Aquaculture. BRAC Prokashana, 66, Mohakhali, Dhaka-1212, Bangladesh. p. 84.

Reid, G.K. 1964. Ecology of Inland Waters and Estuaries. $3^{\text {rd }}$ Printing. Reinhold Publication Corporation, New York. p. 373.

Reid, G.K. and Wood, R.D. 1976. Ecology of Inland Waters and Estuaries. $2^{\text {nd }}$ edition. Van Nostrand, New York. p. 485.

Shahzadi, T., Salim, M., Kalsoom, U. and Shahzad, K. 2006. Growth performance and feed conversion ratio (FCR) of hybrid fingerlings (Catla catla X Labeo rohita) fed on cottonseed meal, sunflower meal and bone meal. Pakistan Vet. J. 26(4): 163-166.

Swingle, H.S. 1967. Standardization of chemical analysis for water and pond muds. FAO Fisheries Report. 4: 397-421.

Zahid, A., Khan, N., Nasir, M. and Ali, M.W. 2013. Effect of artificial feed and fertilization of ponds on growth and body composition of genetically improved farmed tilapia. Pakistan J. Zool. 45(3): 667-671. 